\title{
The Effects of Rice Husk Liquid Smoke in Porphyromonas gingivalis-Induced Periodontitis
}

\author{
Theresia Indah Budhy ${ }^{1}$ Ira Arundina ${ }^{2} \quad$ Meircurius Dwi Condro Surboyo ${ }^{3, \odot}$ Anisa Nur Halimah ${ }^{4}$
}

${ }^{1}$ Department of Oral Pathology and Maxillofacial, Faculty of Dental Medicine, Universitas Airlangga, Surabaya, Indonesia

${ }^{2}$ Department of Oral Biology, Faculty of Dental Medicine, Universitas Airlangga, Surabaya, Indonesia

${ }^{3}$ Department of Oral Medicine, Faculty of Dental Medicine, Universitas Airlangga, Surabaya, Indonesia

${ }^{4}$ Master of Dental Science Program, Faculty of Dental Medicine. Universitas Airlangga, Surabaya, Indonesia

\author{
Address for correspondence Ira Arundina, MSc, Department of Oral \\ Biology, Faculty of Dental Medicine, Universitas Airlangga, Jln. Prof. \\ Dr. Moestopo 47, Surabaya 60132, Indonesia \\ (e-mail: arundinafkg@yahoo.com).).
}

Eur J Dent 2021;15:653-659.

\begin{abstract}
Objectives The purpose of this study was to analyze the effects of rice husk liquid smoke in Porphyromonas gingivalis-induced periodontitis in the inflammatory and proliferation marker such as nuclear factor kappa $\beta$ (NF-kB), tumor necrosis factor- $\alpha$ (TNF- $\alpha$ ), interleukin-6 (IL-6), transforming growth factor- $\beta$ (TGF- $\beta$ ), fibroblast growth factor 2 (FGF2), collagen type 1 (COL-1) expression, and the number of macrophages, lymphocytes, and fibroblasts.

Materials and Methods Rice husk liquid smoke is obtained by the pyrolysis process. Porphyromonas gingivalis-induced periodontitis in $20 \mu \mathrm{L}$ phosphate-buffered saline containing $1 \times 10^{9} \mathrm{CFU}$ was injected into the lower anterior gingival sulcus of Wistar rats. The periodontitis was then treated with $20 \mu \mathrm{L} / 20 \mathrm{~g}$ body weight of rice husk liquid smoke once a day for 2 and 7 days, respectively. After treatment, the bone and lower anterior gingival sulcus were analyzed with immunohistochemistry and hematoxylineosin staining.

Results The treatment of periodontitis with rice husk liquid smoke showed a lower NF-kB, TNF- $\alpha$, and IL- 6 expression and a higher TGF- $\beta$, FGF2, and COL- 1 expression than the control after treatment for 2 and 7 days $(p<0.05)$, respectively. The num-

Keywords

- Porphyromonas ber of macrophages and fibroblasts was also higher when compared with the control group $(p<0.05)$, but the number of lymphocytes was lower than the control $(p<0.05)$. gingivalis

- periodontitis

- liquid smoke

- rice husk Conclusion Rice husk liquid smoke showed its effects on Porphyromonas gingivalis-induced periodontitis with a decrease in inflammatory markers and an increase in proliferation markers. The development of a rice husk liquid smoke periodontitis treatment is promising.
\end{abstract}

\section{Introduction}

Liquid smoke is a result of the wood-burning liquefaction part of the pyrolysis process. ${ }^{1}$ Liquid smoke is traditionally used as a food preservative, especially with fish products, ${ }^{2,3}$ because it maintains protein content ${ }^{4}$ and nutrients and, due to a particular organoleptic characteristic, ${ }^{5}$ prevents bacterial contamination. ${ }^{6}$ Liquid smoke has antibacterial properties because it contains phenolic compounds ${ }^{7}$ and carbonyls. ${ }^{1}$ In lower concentrations, ${ }^{6,8}$ liquid smoke is able to inhibit Gram-negative published online May 26, 2021
DOI https://doi.org/ $10.1055 / \mathrm{s}-0041-1727554$ ISSN 1305-7456
(C) 2021. European Journal of Dentistry.

This is an open access article published by Thieme under the terms of the Creative Commons Attribution-NonDerivative-NonCommercial-License, permitting copying and reproduction so long as the original work is given appropriate credit. Contents may not be used for commercial purposes, or adapted, remixed, transformed or built upon. (https://creativecommons.org/licenses/by-nc-nd/4.0/)

Thieme Medical and Scientific Publishers Pvt. Ltd., A-12, 2nd Floor, Sector 2, Noida-201301 UP, India 
and Gram-positive and fungal growths, such as Escherichia coli, Staphylococcus aureus, ${ }^{6}$ and Candida albicans. ${ }^{9}$

Most types of liquid smoke have a high phenolic compound content and possess antioxidant and antibacterial properties. ${ }^{1}$ The total phenolic compound content in the liquid smoke is dependent on the pyrolysis, wood, and final temperature. In Indonesia, liquid smoke is produced from coconut shells ${ }^{10}$ and rice husks. ${ }^{11,12}$ This liquid smoke has shown a low toxicity ${ }^{11,12}$ and a potential to be beneficial to human health. ${ }^{13}$ Furthermore, rice husk liquid smoke has shown efficiency in the inflammatory process of oral wound healing through the increased recruitment of inflammatory cells and decreased recruitment of proinflammatory cytokines and inflammatory mediators, such as the tumor necrosis factor- $\alpha$ (TNF- $\alpha$ ), interleukin $1 \beta$ (IL-1 $\beta$ ), IL-6, prostaglandin E, and leukotriene B4 (LTB4), ${ }^{14,15}$ by inhibiting reactive oxygen species (ROS) ${ }^{16}$ and nitric oxide. ${ }^{15}$

One of the oral diseases caused by bacteria is periodontitis. The Porphyromonas gingivalis is a Gram-negative bacterium able to produce lipopolysaccharides, which trigger responses from the host. ${ }^{17}$ The host's response to this bacterium includes the activation of fibroblasts and endothelial cells, recruitment of inflammatory cell, such as macrophages and lymphocytes, and the subsequent release of inflammatory mediators and cytokines, which play a crucial role in periodontal tissue destruction..$^{18}$ The role of Porphyromonas gingivalis is to upregulate the nuclear factor kappa B $(\mathrm{NF}-\mathrm{kB})^{19}$ and increase proinflammatory cytokines, such as IL- $6,{ }^{20}$ TNF- $\alpha$, and IL- $1 \beta,{ }^{21}$ through inducing the ROS to activate the JAK2 and c-Jun. ${ }^{22}$

Based on the potential of using liquid smoke against bacteria, we conducted a study on the use of rice husk liquid smoke for the treatment of diseases caused by Porphyromonas gingivalis. The study was conducted by analyzing the expressions of NF-kB, TNF- $\alpha$, IL-6, transforming growth factor $\beta$ (TGF- $\beta$ ), fibroblast growth factor 2 (FGF2), and collagen type 1 (COL-1) as well as the responses of inflammatory cells, such as macrophages, lymphocytes, and fibroblasts.

\section{Materials and Methods}

\section{Liquid Smoke Production}

The use of liquid smoke in this study was based on previous research. ${ }^{11,14}$ Liquid smoke is obtained from rice husks through the pyrolysis process, with a combustion temperature of $400^{\circ} \mathrm{C}$ over 8 hours. The smoke is then condensed using a condenser, then submitted to the distillation process performed using a temperature of 120 to $150^{\circ} \mathrm{C} .{ }^{14}$

\section{Animals}

In this study, the experimental animals used were male Wistar rats (Rattus norvegicus) aged 5 to 6 months, with a weight ranging from 250 to $300 \mathrm{~g}$. The rationale for the choice of age was based on previous studies where the sizes of the mandibles and gingiva were considered sufficiently accessible for bacteria. Research on the experimental animals was performed in the Animal Laboratory at the Faculty of Medicine, Universitas Airlangga, Surabaya, Indonesia.
This research protocol has been approved by the Health Experiment Committee of the Faculty of Dentistry, Airlangga University in Surabaya, with the registration number 160/HRECC.FODM/III/2020.

\section{Porphyromonas gingivalis-Induced Periodontitis}

Periodontitis is obtained by injecting Porphyromonas gingivalis (Pg ATCC 33277 PK/5, Thermo Scientific) with the formulation of $1 \times 10^{9} \mathrm{CFU}$ in $20 \mu \mathrm{L}$ phosphate-buffered saline into the gingival sulcus between the two lower mandibular incisors using a $0.5-\mathrm{mL}$ syringe. ${ }^{23}$

The Porphyromonas gingivalis injection is performed every 3 days for 14 days. ${ }^{24}$ On the fourteenth day and after, clinical signs of periodontitis will be seen. The criteria of these signs are a reddish coloring of the gingiva, swelling of the interdental incisive central mandibular area, and interdental resorption by histopathology examination.

\section{Treatment Using Rice Husk Liquid Smoke}

Rice husk liquid smoke was slowly inserted into the gingival sulcus, ${ }^{25}$ using a 1 -mL syringe with a unbeveled needle $(13 \mathrm{~mm} \times 0.04 \mathrm{~mm})$ (Terumo, Japan), while the control group was given sterile water. During the application process, the oropharyngeal regions of the experimental animals were covered with sterile gauze to prevent the ingestion of rice husk liquid smoke. This treatment was performed once a day for 2 and 7 days. The dosage used was $20 \mu \mathrm{L} / 20$ g body weight. ${ }^{15}$

NF-kB, TNF- $\alpha$, IL-6, TGF- $\beta$, FGF2, and COL-1 Expression Lower central incisive and alveolar bone tissue was collected after preceded euthanasia by $\mathrm{CO}_{2}$ inhalation on days 2 and 7 after rice husk liquid smoke treatment. The immunohistochemistry staining used the standard method of streptavidin-biotin-peroxidase complex to bind primary antibodies, using the LSAB System Universal Kit. Diaminobenzidine tetrahydrochloride was used as chromogen and counterstained with Mayer's hematoxylin.

The primary antibody used was NF-kB (anti-p65 antibody [nuclear Factor-KB P65], polyclonal, anti-body online $\mathrm{GmbH}$, Germany), TNF- $\alpha$ (anti-TNF $\alpha$ antibody, polyclonal, anti-body online GmbH, Germany), IL-6 (anti-IL6 antibody, polyclonal, anti-body online $\mathrm{GmbH}$, Germany), TGF- $\beta$ (anti-TGFB1 antibody, polyclonal, anti-body online $\mathrm{GmbH}$, Germany), FGF2 (anti-FGF2 antibody, polyclonal, anti-body online GmbH, Germany), and COL-1 (anti-collagen, type I antibody, monoclonal, anti-body online $\mathrm{GmbH}$, Germany). All measurements were made using a light microscope (Nikon H600L microscope; Nikon, Japan) with a magnification of $1,000 \times$ at five fields of view with a single blind operator.

\section{Number of Macrophages, Lymphocytes, and Fibroblasts}

The number of macrophages, lymphocytes, and fibroblasts was analyzed using hematoxylin and eosin. All measurements were made using a light microscope (Nikon H600L microscope; Nikon, Japan) with a magnification of $400 \times$ at five fields of view with a single blind operator. 


\section{Statistical Analysis}

The differences of each expression and the cell numbers were analyzed using ' with an independent $t$-test. A $p$-value of $<0.05$ is considered as a significant difference for each group.

\section{Results}

\section{NF-kB, TNF- $\alpha$, and IL-6 Expression}

After 2 days of treatment with rice husk liquid smoke, there were no differences in NF-kB, TNF- $\alpha$, and IL-6 expressions $(p=0.146 ; p=0.139 ; p=0.198)(p<0.05)$ compared with the control group. Meanwhile, after 7 days of rice husk liquid smoke treatment, the NF-kB, TNF- $\alpha$, and IL- 6 expressions were all lower when compared with the control group $(p=0.000)(p<0.05)$ (-Table 1). The NF-kB, TNF- $\alpha$, and IL-6 expressions are presented in - Fig. 1.

\section{TGF- $\beta$, FGF2, and COL- 1 Expression}

The 2-day rice husk liquid smoke treatment of the periodontal pocket showed that the TGF- $\beta$, FGF2, and COL-1 expressions ( $p=0.002 ; p=0.003 ; p=0.000)(p<$ 0.05 ) were higher when compared with the control group. The same results also showed higher TGF- $\beta$, FGF2, and COL-1 expressions $(p=0.004 ; p=0.001 ; p=0.001)(p<0.05)$ when compared with the control group after the 7-day rice husk liquid smoke treatment of the periodontal pocket (-Table 1). The TGF- $\beta$, FGF2, and COL-1 expressions are presented in - Fig. 2.

\section{Number of Macrophages, Lymphocytes, and Fibroblasts}

The 2-day rice husk liquid smoke treatment showed a higher number of macrophages compared with the control group $(p=0.004)(p<0.05)$. The same results also showed a higher number of macrophages when compared with the control group $(p=0.003)(p<0.05)$ after the 7-day rice husk liquid smoke treatment ( - Table 1 ; - Fig. 3 ).

In contrast, the 2-day rice husk liquid smoke treatment showed a lower number of lymphocytes when compared with the control group ( $p=0.013$ ), and after the 7-day rice husk liquid smoke treatment the experimental group showed a lower number of lymphocyte cells when compared with the control group $(p=0.001)(p<0.05)$ (-Table 1; -Fig. 3).

The 2-day rice husk liquid smoke treatment showed a higher number of fibroblasts when compared with the control group $(p=0.000)(p<0.05)$. The same results also showed a higher number of fibroblasts when compared with the control group $(p=0.001)(p<0.05)$ after the 7-day rice husk liquid smoke treatment (-Table 1 ; - Fig. 3 ).

\section{Discussion}

The role of Porphyromonas gingivalis in the tissue destruction related to periodontitis is connected to Toll-like receptor 4 (TLR4). The activation of TLR4 can activate Myd88-dependent pathways. When the Myd88 is activated, this protein will activate the NF-kB and activator protein-1 as well as the inflammatory gene. ${ }^{26}$ The activation of NF-kB increases the production of proinflammatory cytokines, such as TNF- $\alpha$ and IL-6, resulting in the tissue destruction related to periodontitis. The treatment of periodontitis with rice husk liquid smoke is able to interfere with the inflammatory process, including the activation of NF-kB and proinflammatory cytokines, such as TNF- $\alpha$ and IL-6.

Rice husk liquid smoke contains several types of phenolic compounds, in the form of 2-methoxyphenol (guaiacol), mequinol, phenol, and 4-ethylguaiacol, ${ }^{11}$ which can increase the expression and activation of the Nrf2 signaling pathway $^{27}$ and inhibit the expression activation of the NF-kB/IkB $\alpha$ signaling pathway. ${ }^{28}$ 4-Ethylguaiacol increases the production and releases Nrf2 into the nucleus to prevent the

Table 1 The NF-kB, TNF- $\alpha$, IL-6, TGF- $\beta$, FGF2, and COL-1 expression and the number of macrophages, lymphocytes, and fibroblast after treatment with rice husk liquid smoke

\begin{tabular}{|c|c|c|c|c|c|c|}
\hline \multirow[t]{2}{*}{ Marker } & \multicolumn{3}{|c|}{$\begin{array}{l}\text { Treatment for } 2 \text { days } \\
(X \pm S D)\end{array}$} & \multicolumn{3}{|c|}{$\begin{array}{l}\text { Treatment for } 7 \text { days } \\
(X \pm S D)\end{array}$} \\
\hline & RHLS & Control & $p$-Value & RHLS & Control & $p$-Value \\
\hline NF-kB expression & $5.20 \pm 1.92$ & $7.00 \pm 1.58$ & 0.146 & $2.60 \pm 1.14$ & $10.20 \pm 1.92$ & $0.000^{\mathrm{a}}$ \\
\hline TNF- $\alpha$ expression & $9.20 \pm 1.48$ & $11.40 \pm 2.51$ & 0.139 & $5.20 \pm 1.92$ & $13.40 \pm 2.51$ & $0.000^{\mathrm{a}}$ \\
\hline IL-6 expression & $7.80 \pm 1.79$ & $9.80 \pm 2.59$ & 0.198 & $2.80 \pm 0.84$ & $12.60 \pm 2.07$ & $0.000^{\mathrm{a}}$ \\
\hline TGF- $\beta$ expression & $11.20 \pm 2.16$ & $4.60 \pm 2.41$ & $0.002^{\mathrm{a}}$ & $13.40 \pm 1.43$ & $6.00 \pm 1.87$ & $0.004^{\mathrm{a}}$ \\
\hline FGF2 expression & $11.20 \pm 1.92$ & $3.20 \pm 1.92$ & $0.003^{\mathrm{a}}$ & $13.40 \pm 2.86$ & $4.60 \pm 2.07$ & $0.001^{\mathrm{a}}$ \\
\hline COL-1 expression & $11.40 \pm 2.30$ & $3.10 \pm 1.14$ & $0.000^{\mathrm{a}}$ & $13.40 \pm 2.41$ & $5.40 \pm 2.30$ & $0.001^{\mathrm{a}}$ \\
\hline Macrophages & $10.60 \pm 1.52$ & $5.40 \pm 2.30$ & $0.004^{\mathrm{a}}$ & $12.40 \pm 2.07$ & $6.60 \pm 2.30$ & $0.003^{\mathrm{a}}$ \\
\hline Lymphocytes & $7.80 \pm 1.92$ & $12.80 \pm 2.77$ & $0.013^{a}$ & $3.40 \pm 1.14$ & $14.60 \pm 3.21$ & $0.001^{\mathrm{a}}$ \\
\hline Fibroblast & $10.20 \pm 1.92$ & $3.40 \pm 1.67$ & $0.000^{\mathrm{a}}$ & $13.40 \pm 2.51$ & $6.20 \pm 1.92$ & $0.001^{\mathrm{a}}$ \\
\hline
\end{tabular}

Abbreviations: COL-1, collagen type 1; FGF2, fibroblast growth factor 2; IL-6, interleukin-6; NF-kB, nuclear factor kappa $\beta$, RHLS, rice husk liquid smoke; TGF- $\beta$,transforming growth factor- $\beta$, TNF- $\alpha$, tumor necrosis factor- $\alpha$.

Note: $X \pm$ SD: mean \pm standard deviation

asignificant difference using independent $t$-test with $p<0.05$. 

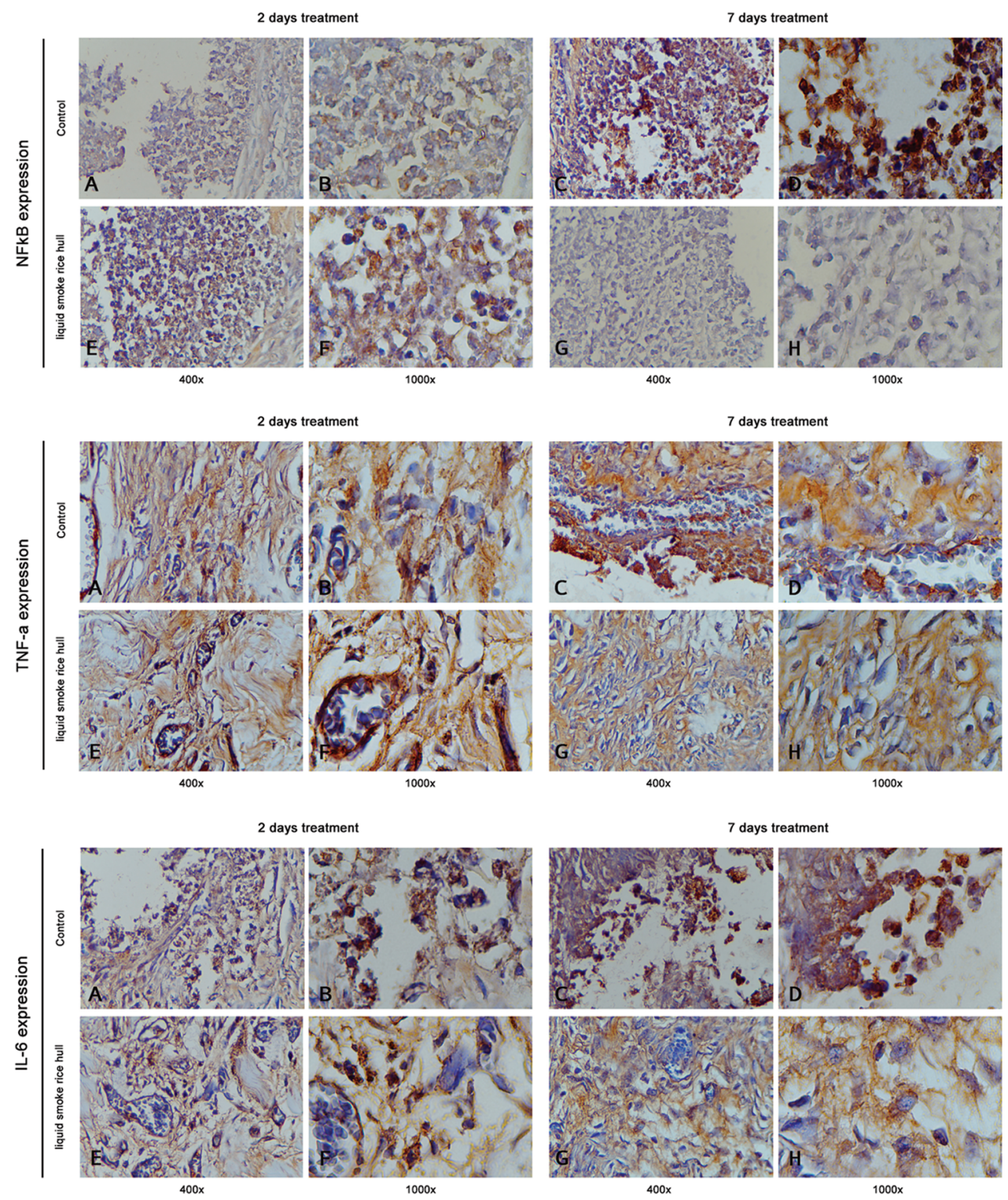

Fig. 1 The nuclear factor kappa $\beta$ (NF-kB), tumor necrosis factor- $\alpha$ (TNF- $\alpha$ ), and interleukin-6 (IL-6) expression. (A, B) Control for 2 days; (C, D) control for 7 days; (E, F) treatment with liquid smoke rice hull for 2 days; $(\mathbf{G}, \mathbf{H})$ treatment with liquid smoke rice hull for 7 days.

phosphorylation of $\mathrm{NF}-\mathrm{kB} / \mathrm{IkB} \alpha$, thereby reducing inflammatory activation and the release of inflammatory cytokines. The antioxidant properties of 4-ethylguaiacol can be contributed to the inhibition of inflammation by scavenger of ROS and increase inflammatory response, ${ }^{29}$ by inhibiting the activation of NF-kB to produce proinflammatory cytokines, such as TNF- $\alpha$ and IL-6. ${ }^{10}$

On a cellular level, rice husk liquid smoke treatment is able to interfere with the responses of inflammatory cells, such as macrophages and lymphocytes. The 2- and 7-day rice husk liquid smoke treatments showed an increased number of macrophages. The same results also showed a higher number of macrophages after the 7-day rice husk liquid smoke treatment. In contrast, the 2- and 7-day rice husk liquid smoke treatments showed a lower number of lymphocytes. This condition is a result of the inhibition of proinflammatory cytokine production. A previous study also confirmed this condition. This is because the main content of phenolic compounds in distilled liquid smoke rice can inhibit free radicals, thereby accelerating the recruitment of inflammatory cells and accelerating the inflammatory process. ${ }^{14}$ In the condition of periodontitis, rice husk liquid smoke can inhibit tissue damage with the toxins produced by periodontal bacteria accelerating the inflammatory response.

Not only the inflammatory process, but also the proliferation stage, is affected by rice husk liquid smoke. The TGF- $\beta$, FGF2, and COL-1 expressions, as indicators of proliferation, also change. The mechanism involved is resolution of the inhibition of the inflammation process. With the inhibition of free radical formation, the transcription factor for the formation of anti-inflammatory cytokines and growth factors, namely Nrf2, will be activated. Previous studies have shown that application of rice husk liquid smoke can increase the 

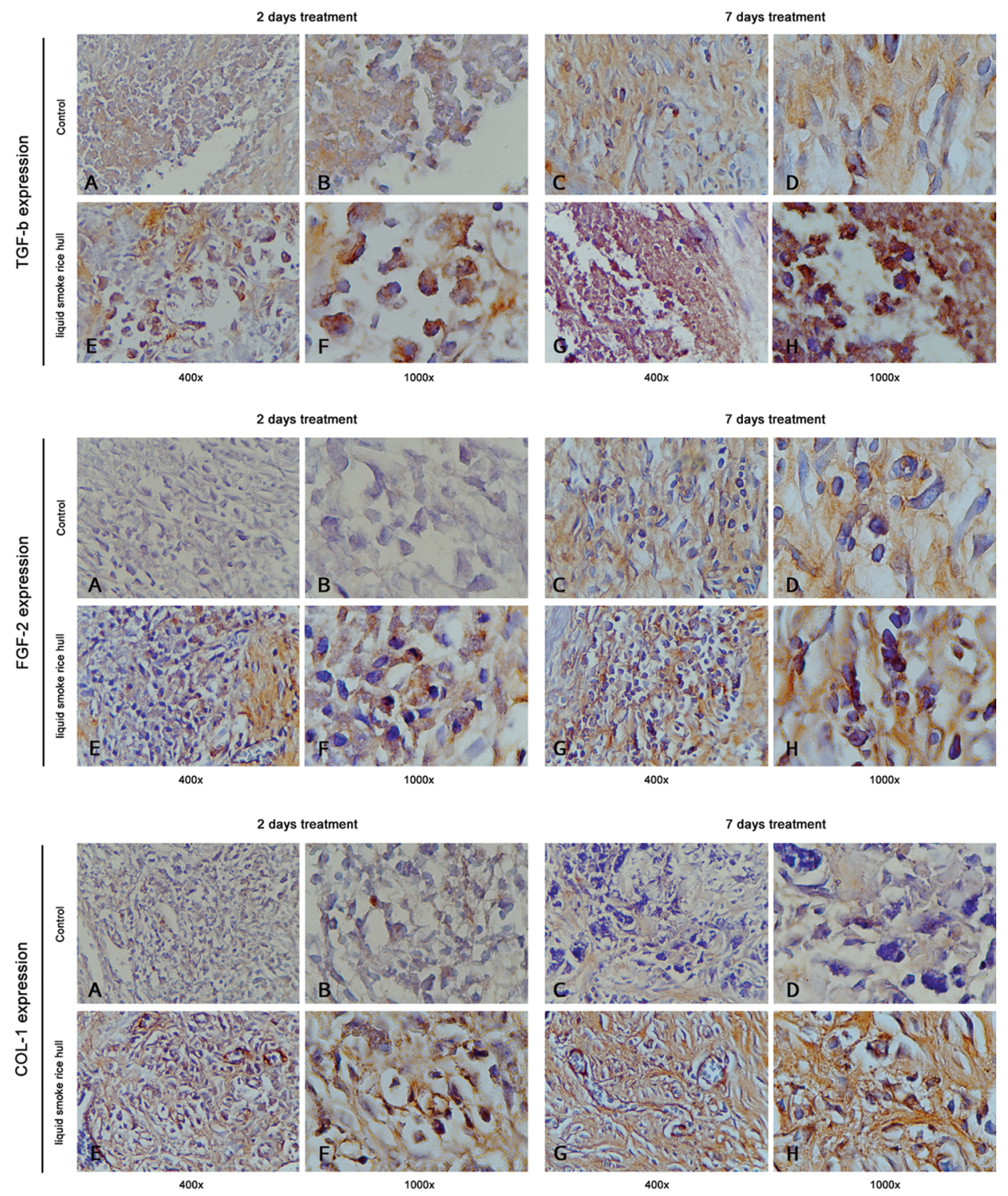

Fig. 2 The transforming growth factor- $\beta$ (TGF- $\beta$ ), fibroblast growth factor 2 (FGF2), and collagen type 1 (COL-1) expression. (A, B) Control for 2 days; (C, D) control for 7 days; (E, F) treatment with liquid smoke rice hull for 2 days; (G, H) treatment with liquid smoke rice hull for 7 days.

formation of growth factors, such as TGF- $\beta,{ }^{14} \mathrm{FGF}$, and vascular endothelial growth factors. ${ }^{14,30}$ In this research, it can also be seen that growth factors, such as TGF- $\beta$, FGF, and COL-1 expressions, increased with rice husk liquid smoke treatment.

The increase of growth factors after rice husk liquid smoke treatment also affected the fibroblast number. As a healing marker, fibroblast was also affected after treatment. The 2- and 7-day rice husk liquid smoke treatments showed a higher number of fibroblasts. The increased number of fibroblasts was due to the decrease in the inflammatory process and the increase in the number of growth factors. The phenolic compound is responsible for this process because it is able to increase the inflammatory cell response and inhibit the production of proinflammatory mediators. ${ }^{31,32}$

Another reason for this effect of rice husk liquid smoke is its ability to inhibit Gram-negative and Gram-positive bacteria, such as Porphyromonas gingivalis, in the progression of periodontitis. ${ }^{1}$ Phenolic compounds are known to disturb the cytoplasmic membranes of bacteria and cause the intracellular fluids to leak. ${ }^{33,34}$ Carbonyls inhibit microbial growth by penetrating the cell wall and inactivating enzymes located in the cytoplasm and the cytoplasmic membrane. Carbonyls act by condensing the free primary amino groups in the polypeptide chains, primarily in the side chains of basic amino acids. These amino groups may be an essential part of the active site of the enzyme, or they may function as a binder for the substrate by hydrogen bonding. ${ }^{1}$

\section{Conclusion}

Rice husk liquid smoke showed its effect on the periodontitis condition by decreasing the inflammatory markers, such as lymphocytes and NF-kB, TNF- $\alpha$, and IL-6 expressions, 

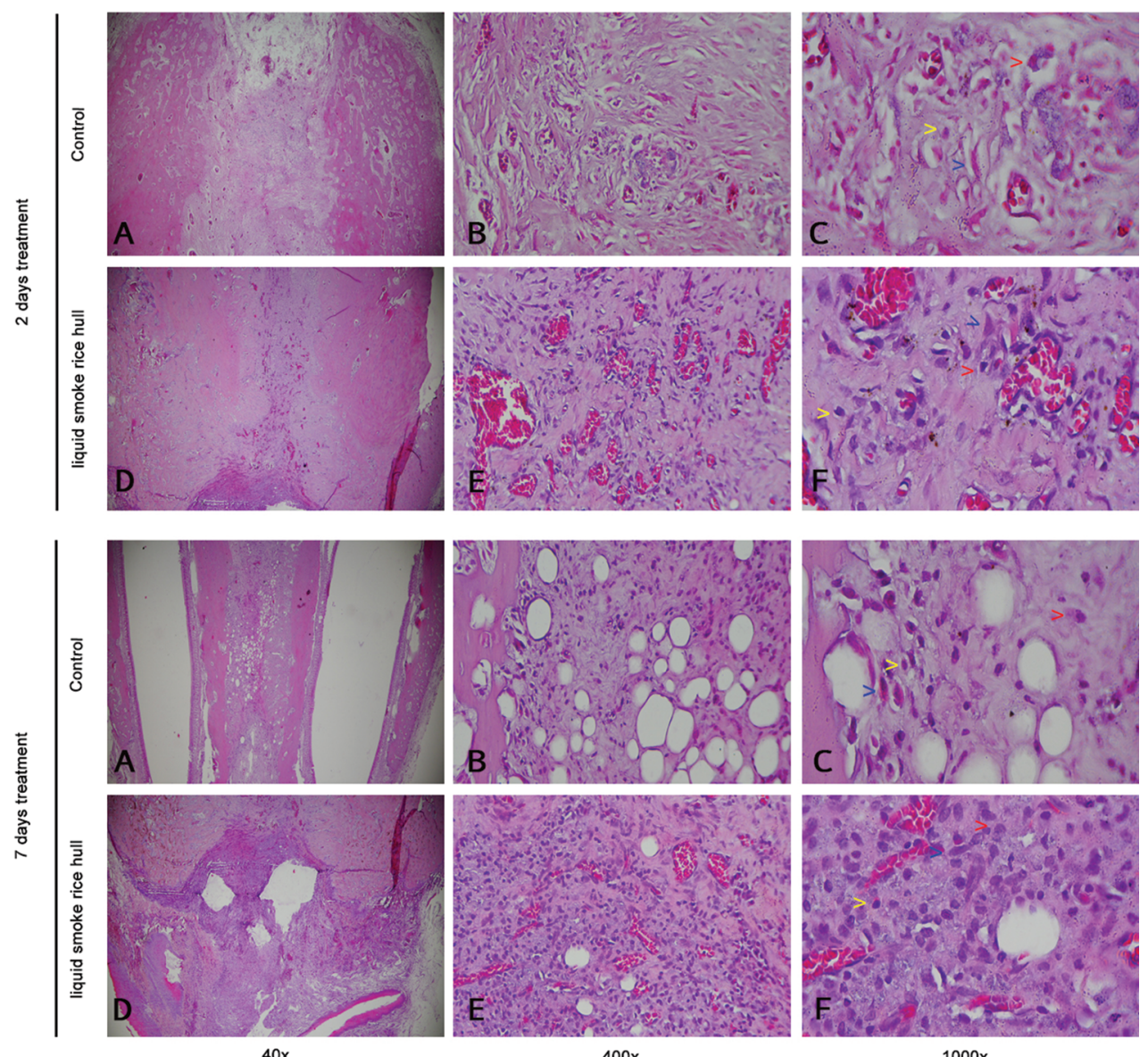

$400 x$

$1000 x$

Fig. 3 The number of macrophages (red arrow), lymphocytes (yellow arrow), and fibroblast (blue arrow). (A, B) Control for 2 days; (C, D) control for 7 days; (E, F) treatment with liquid smoke rice hull for 2 days; $(\mathbf{G}, \mathbf{H})$ treatment with liquid smoke rice hull for 7 days.

and increased the proliferation markers, such as the number of macrophages, fibroblasts, and TGF- $\beta$, FGF2, and COL-1 expressions. The use of rice husk liquid smoke is promising in periodontitis treatment.

\section{Funding}

This study was funded by Ministry of Higher Education, Republic of Indonesia 2020 in the schema PENELITIAN DASAR UNGGULAN PERGURUAN TINGGI (PDUPT) (funding number 630/UN3.14/PT/2020).

\section{Conflict of Interest}

None declared.

\section{References}

1 Lingbeck JM, Cordero P, O'Bryan CA, Johnson MG, Ricke SC, Crandall PG. Functionality of liquid smoke as an all-natural antimicrobial in food preservation. Meat Sci 2014;97(2):197-206

2 Nithin CT, Joshy CG, Chatterjee NS, et al. Liquid smoking - a safe and convenient alternative for traditional fish smoked products. Food Control 2020;113(July):107186

3 Saloko S, Darmadji P, Setiaji B, Pranoto Y. Antioxidative and antimicrobial activities of liquid smoke nanocapsules using chitosan and maltodextrin and its application on tuna fish preservation. Food Biosci 2014;7:71-79

4 Yusnaini S, Suryanto E, Armunanto R. Physical, chemical and sensory properties of kenari (Canariun indicum L.) shell liquid smoke-immersed-beef on different level of dilution. J Indones Trop Anim Agric 2012;37(1):27-33

5 Sokamte Tegang A, Mbougueng PD, Sachindra NM, Douanla Nodem NF, Tatsadjieu Ngoune L. Characterization of volatile compounds of liquid smoke flavourings from some tropical hardwoods. Sci African 2020;8:e00443

6 Soares JM, da Silva PF, Puton BMS, et al. Antimicrobial and antioxidant activity of liquid smoke and its potential application to bacon. Innov Food Sci Emerg Technol 2016;38:189-197

7 C T N, Sekhar Chatterjee N, C G J, et al. Source-dependent compositional changes in coconut flavoured liquid smoke and its application in traditional Indian smoked fishery products. Food Addit Contam Part A Chem Anal Control Expo Risk Assess 2020;37(10):1610-1620

8 Faisal M, Gani A, Mulana F. Preliminary assessment of the utilization of durian peel liquid smoke as a natural preservative for mackerel. F1000 Res 2019;8:240

9 Kailaku S, Syakir M, Mulyawanti I, Syah A. Antimicrobial activity of coconut shell liquid smoke. IOP Conf Ser Mater Sci Eng 2017;206:12050

10 Surboyo MDC, Arundina I, Rahayu RP, Mansur D, Bramantoro T. Potential of distilled liquid smoke derived from coconut (Cocos nucifera $\mathrm{L}$ ) shell for traumatic ulcer healing in diabetic rats. Eur J Dent 2019;13(2):271-279

11 Arundina I, Diyatri I, Surboyo MDC. The component analysis of liquid smoke from rice hulls and its toxicity test on baby hamster kidney cells. J Pharm Phyther Res. 2021;9(1):78-87

12 Arundina I, Tantiana T, Diyatri I, Surboyo MDC, Adityasari R. Acute toxicity of liquid smoke of rice hull (Oryza sativa) on mice (Mus musculus) J. Int Dent Med Res. 2020;13(1):91-96 
13 Tarawan VM, Mantilidewi KI, Dhini IM, Radhiyanti PT, Sutedja E. Coconut shell liquid smoke promotes burn wound healing. J Evid Based Complementary Altern Med 2017;22(3): 436-440

14 Arundina I, Diyatri I, Kusumaningsih T, Surboyo MDC, Monica E, Afanda NM. The role of rice hull liquid smoke in the traumatic ulcer healing. Eur J Dent 2020;15(1):33-38

15 Kim SP, Yang JY, Kang MY, Park JC, Nam SH, Friedman M. Composition of liquid rice hull smoke and anti-inflammatory effects in mice. J Agric Food Chem 2011;59(9):4570-4581

16 Yang JY, Kang MY, Nam SH, Friedman M. Antidiabetic effects of rice hull smoke extract in alloxan-induced diabetic mice. J Agric Food Chem 2012;60(1):87-94

17 Rafiei M, Kiani F, Sayehmiri F, Sayehmiri K, Sheikhi A, Zamanian Azodi M. Study of Porphyromonas gingivalis in periodontal diseases: a systematic review and meta-analysis. Med J Islam Repub Iran 2017;31:62

18 Elkaim R, Bugueno-Valdebenito IM, Benkirane-Jessel N, Tenenbaum H. Porphyromonas gingivalis and its lipopolysaccharide differently modulate epidermal growth factor-dependent signaling in human gingival epithelial cells. J Oral Microbiol 2017;9(1):1334503

19 Groeger S, Jarzina F, Domann E, Meyle J. Porphyromonas gingivalis activates NFKB and MAPK pathways in human oral epithelial cells. BMC Immunol 2017;18(1):1

20 Watanabe N, Yokoe S, Ogata Y, Sato S, Imai K. Exposure to Porphyromonas gingivalis induces production of proinflammatory cytokine via TLR2 from human respiratory epithelial cells. J Clin Med 2020;9(11):3433

21 Son G-Y, Bak E-J, Kim J-H, et al. Endothelin regulates porphyromonas gingivalis-induced production of inflammatory cytokines. PLoS One 2016;11(12):e0167713

22 Wang H, Zhou H, Duan X, et al. Porphyromonas gingivalisinduced reactive oxygen species activate JAK2 and regulate production of inflammatory cytokines through c-Jun. Infect Immun 2014;82(10):4118-4126

23 Arundina IRA, Diyatri I, Surboyo MDC, Halimah AN, Chusnurrafi FI. The antibacterial effect of liquid smoke rice hull on porphyromonas gingivalis and its proliferative effects on osteoblast as periodontitis remedies: an in vitro study. Int J Pharm Res. 2020;12(03):3466-3471

24 Ridwan RD, Tantiana T, Setijanto D, Kusuma AK, Putranto AF. The ability of electrolyzed reduced water to act as an antioxidant and anti-inflammatory agent in chronic periodontitis Wistar rats (Rattus novergicus). Kafkas Univ Vet Fak Derg 2019;25(4):539-544

25 Santos BFE, Souza EQM, Brigagão MRPL, Lima DC, Fernandes LA. Local application of statins in the treatment of experimental periodontal disease in rats. J Appl Oral Sci 2017;25(2):168-176

26 Jia L, Han N, Du J, Guo L, Luo Z, Liu Y. Pathogenesis of important virulence factors ofPorphyromonas gingivalis via Toll-like receptors. Front Cell Infect Microbiol 2019;9:262

27 Zhao DR, Jiang YS, Sun JY, Li HH, Luo XL, Zhao MM. Anti-inflammatory mechanism involved in 4-ethylguaiacolmediated inhibition of LPS-induced inflammation in THP-1 cells. J Agric Food Chem 2019;67(4):1230-1243

28 Zhao DR, Jiang YS, Sun JY, Li HH, Sun XT, Zhao MM. Amelioration of 4-methylguaiacol on LPS-induced inflammation in THP- 1 cells through NF-KB/IKB $\alpha / \mathrm{AP}-1$ and Nrf2/HO-1 signaling pathway. J Funct Foods 2019;55(January) :95-103

29 Zhao D, Sun J, Sun B, et al. Intracellular antioxidant effect of vanillin, 4-methylguaiacol and 4-ethylguaiacol: three components in Chinese Baijiu. RSC Advances 2017;7(73):46395-46405

30 Ayuningtyas NF, Dwi M, Surboyo C, Ernawati DS, Parmadiati AE. The role of liquid smoke coconut shell in the proliferation phase of an oral traumatic ulcer. J Pharm Pharmacogn Res. 2020;8(6):549-557

31 Surboyo MDC, Mahdani FY, Ernawati DS, Sarasati A, Rezkita F. The macrophage responses during diabetic oral ulcer healing by liquid coconut shell smoke: an immunohistochemical analysis. Eur J Dent 2020;14(3):410-414

32 Ernawati DS, Surboyo MDC, Ayuningtyas NF, Nagoro AAB. Role of inflammatory cell responses in stimulating fibroblasts in diabetic oral ulcer after treatment with liquid smoke of coconut endocarp: a histological assessment. Eur J Dent 2020;15(1):71-76

33 Aldulaimi OA. General overview of phenolics from plant to laboratory, good antibacterials or not. Pharmacogn Rev 2017;11(22):123-127

34 Papuc C, Goran GV, Predescu CN, Nicorescu V, Stefan G. Plant polyphenols as antioxidant and antibacterial agents for shelflife extension of meat and meat products: classification, structures, sources, and action mechanisms. Compr Rev Food Sci Food Saf 2017;16(6):1243-1268 